\title{
CORRELATION OF COMPUTER-MEDIATED COMMUNICATION WITH RISKY SEXUAL BEHAVIOURS IN REGARDS TO ADOLESCENT STUDENTS PHYSICAL LOCATION
}

\section{MKPOIKANKE SUNDAY OTU ${ }^{1}$, JOACHIM CHINWEIKE OMEJE ${ }^{2}$, NNEKA CHARITY NWOSU ${ }^{3 *}$, FAVOUR MKPOIKANKE OTU ${ }^{4}$, STELLA ANIETIE USEN ${ }^{5}$, ROWLAND UWAKWE ${ }^{6}$, GRACE $^{\circ}$ AKANIYENE ENEH ${ }^{7}$, INWANG ETIM UDOM ${ }^{8}$ \& VICTOR CHIJIOKE NWOSUMBA ${ }^{9}$ \\ ${ }^{1,2,3,4}$ Department of Educational Foundations, University of Nigeria, Nsukka, 410001, Enugu State, Nigeria \\ ${ }^{5}$ Department of Educational Foundations, College of Education, AfahaNsit, Akwa Ibom State}

${ }^{6}$ Department of Educational Foundation, Faculty of Education, Alex Ekwueme Federal University Ndufu-Alike Ikwo, Ebonyi State, Nigeria

${ }^{7}$ Department of Primary Education, College of Education, AfahaNsit, Akwa Ibom State

${ }^{8}$ Department of Education Foundations, Guidance and Counselling, University of Uyo, Uyo, Akwa Ibom State, Nigeria

${ }^{9}$ Department of Political Science, Alex Ekwueme Federal University Ndufu-Alike IkwoEbonyi State, Nigeria

\section{ABSTRACT}

The current study determined the extent of relationship between computer-mediated communication and risky sexual behaviors among in-school adolescents in regards to students' physical location using correlation design. Two instruments, namely: In-School Adolescents' Use of Computer-Mediated Communication (ISAUCMCQ) and In-School Adolescents' Risky Sexual Behaviors Questionnaire (ISARSBQ) were used for data collection in the study. The data collected were analysed using Partial correlation statistics, bar chart and regression statistics and hypothesis was tested at 0.05 level of significance. It was found that the correlation between computer-mediated communication and risky sexual behavior among in-school adolescents was statistically significant in regards to students' physical location.

KEYWORDS: Computer-Mediated Communication, In-School Adolescents, Risky Sexual Behaviors

Received: Jun 08, 2020; Accepted: Jun 28, 2020; Published: Aug 11, 2020; Paper Id.: IJMPERDJUN2020730

\section{INTRODUCTION}

The use of computer devices for interpersonal communication, which is known as "Computer-mediated communication", has become a widespread in Nigeria recently. Many people have engaged in electronic messaging, computer conferencing and electronic interactions more than using postal services. On a general note, people (including in-school adolescents) have dived into the use of computerized devices to facilitate interpersonal interactions. Bishop (2009) observed that computer-mediated communication has to do with communications via messaging applications, social networking platforms (e.g., Facebook, 2go, WhatsApp, BBM, Badoo, Skype, Twitter, Instagram, Pinterest, Myspace, Skyrock, Usenet, YouTube, Foursquare), e-mails, blogs, video, audio, phone, and online calls.

According to Lenhart, Ling, Campbell and Purcell (2010) and Postmes, Spears and Lea (2013), computermediated communication has the power to enable individuals to break social boundaries and become liberated from 
social influence and group pressure. Jiang, Bazarova and Hancock (2011) noticed that computer-mediated communication is marked with higher levels of self-disclosure in conversation as opposed to face-to-face interactions due, in part, to visual anonymity and the absence of nonverbal cues which reduce concern for losing positive face. According to Walther's (1996) hyperpersonal communication model, computer-mediated communication is valuable in providing a better communication and better first impressions. Campbell and Park (2014) asserted that computer-mediated communication plays an integral role in the emancipation process by providing young people with the autonomy and flexibility to connect with their peers and carry out their social lives. According to Ling (2004), computer-mediated communication has emerged as the most integral resource that adolescents use to exercise their autonomy and align themselves with peer culture because of its communicative function and may predispose adolescents to risky sexual behaviours.

Risky sexual behavior means behaviours that amplify one's risk of contracting sexually transmitted infections or experiencing unintended pregnancies. Such behaviours include having sex at an early age, especially before 18 years of age, having multiple sexual partners, having sex while under the influence of alcohol or drugs, unprotected sexual intercourse including unprotected genital, oral or anal sex with infected person, having sex with somebody who has a multiple sex partners, having sex with a partner who injects or has ever injected drugs, exchange of sex (sex work) for drugs or money, unwanted kissing, unwanted caressing, rape and sexual abuse, among others(Centers for Disease Control and Prevention, 2010; WHO, 2014; UNICEF, 2014), though location in which the individual operates may play a role in this subject matter.

Location is an umbrella name referring to urban and rural areas. Urban area is an area within the jurisdiction of a municipality or town committee, with a large population and availability of some basic social amenities like; good roads, internet services, global system of mobile communication (GSM) networks, electric power supply and health facilities, among others. Rural area is an area with less dense population, with little or no social amenities (UNESCO, 2012). The rural and urban communities differ in many respects including the accessibility of electronic information. Urban adolescents may have more tendencies to use the computer-mediated communication systems. The level of education and awareness about the use and misuse of the computer-mediated communication devices, for instance, may also be high among parents in urban areas. Most of the rural parents in Nigeria are not very much exposed to the computer-mediated communication devices and their awareness about its use and misuse may be limited. It may be possible that the rural adolescents with their rustic curiosity may explore and experiment the possibilities of the communication systems when they are exposed to such modern technology for the first time while the urban adolescents have the opportunity of getting more information about the possibilities of use as well as abuse of the internet, for instance. Correspondingly, the risky sexual behaviours of adolescents in the rural and urban areas may differ based on the differences in their engagement in computer-mediated communication or social networks (Koovakkai \& Muhammed, 2010).

Adolescents look to social networks as a key source of information and advice in a critical developmental period. In a study by Nielsen (2009), 57\% of adolescents agreed that they look to their online social network for advice. In another study by Lenhart (2010), 31\% of adolescents also use online searches to gain answers to many of their health concerns, $31 \%$ of online adolescents get health, dieting, or physical fitness information from the internet while $70 \%$ of adolescents who use the internet report they use it to gather information about health topics that are hard to discuss with others, such as drug use and sexual health. Cross and Morgan (2003) had earlier blamed the media for the changing sexual attitudes and behaviours of students. Students currently receive more sex education through Life Orientation, peer education and 
through media, for example, TV programmes. Cross and Morgan (2003) argue that sexual attitudes and behaviours of students have not changed throughout the recent history through sex education. This has resulted in a generation who engages in sexual experimentation earlier than ever before, dangerously mixes alcohol and sex, and can access sex or sex information 24 hours a day with just the click of a mouse (Cross \& Morgan, 2003). Consequently, Berkman (2010) observed that while social media use is an integral part of the daily life of adolescents, there are a number of risks associated with social media use including, negative effects on mental health, cyberbullying, texting or sexting, dangers of sexual solicitation, and exposure to problematic and illegal content and privacy violations that may lead to risky sexual behaviours.

However, it is not clear whether location can contribute to the relationship between computer-mediated and risky sexual behaviour. Meanwhile, previous studies do not consider the mediating effect of location in the relationship between computer-mediated and risky sexual behaviours. For instance, Dineshan and Said (2010)found out that as compared to the urban adolescents, the internet abuse in terms of habit of changing or manipulating information on the internet, opinion about giving false information on the internet, habit of downloading vulgar pictures or pornographic items, plagiarism, tendency of sending unwanted messages is more among the rural adolescents. This could be because of their ignorance about the negative impact of the use of internet. Voeten, Egesah and Habbema(2004) found out that for women, sexual behaviour was more risky in rural than in urban areas; that rural women reported less frequently being a virgin at marriage, a higher number of lifetime partners, and less consistent condom use with non-spousal partners; Atav and Spencer (2002) discovered that rural-dwelling students engage in risky sexual activities more than urban-dwelling ones and the present study will lend credence to or disapprove this fact. The focus of the present study is therefore to investigate the correlation of computer-mediated communication with risky sexual behavioursin regards to students' physical location.

\section{METHOD}

The study was carried out in Uyo Education zone of Akwa Ibom State, Nigeria. This education zone comprises only Uyo Local Government Area, which is the Capital of Akwa Ibom State. Uyo Education Zone has 14 secondary schools (6 in the urban area and 8 in the rural area). Uyo is a city in south-south Nigeria and the capital of Akwa Ibom State, a major oil producing state of Nigeria. The city became the capital of Akwa Ibom State on September 23, 1987 following the creation of Akwa Ibom State from erstwhile Cross River State.

The population of this study comprised of 5863 senior secondary school two (SSII) students in public secondary schools in Uyo Education Zone of Akwa Ibom state -2015/2016 school session. A sample of the study comprised all 415 SSII in-school adolescents who used computer-mediated communication in all the 14 public secondary schools in Uyo Education Zone of Akwa Ibom State. A pre-survey was conducted by the researcher to identify these in-school adolescents. The inclusion criteria involved the in-school adolescents scoring $50 \%$ and above in the computer-mediated communication eligibility questionnaire. The researcher kept contact details (such as the name, school and class) of the inschool adolescents who met the inclusion criteria to enable easy access during the actual study.

For the pre-survey, Computer-Mediated Communication Eligibility Questionnaire - (CMCEQ) with "Yes" or "No" response format, was developed by the researcher and used to ascertain in-school adolescents that were eligible for the study. In the actual study, two instruments were used for data collection: In-School Adolescents' Computer-Mediated Communication Questionnaire (ISACMCQ) and In-School Adolescents' Risky Sexual Behaviours Questionnaire (ISARSBQ). 

Rowland Uwakwe, Grace Akaniyene Eneh, Inwang Etim Udom \& Victor Chijioke Nwosumba

ISAUCMCQ is a researcher-developed questionnaire. The questionnaire has two sections $-\mathrm{A}$ and B. Section A sought for personal information such as gender and location. Section B has 19 items that focused on the extent of in-school adolescents' engagement in computer-mediated communication. ISARSBQ is also researcher-developed questionnaire. with 16 items that focused on the extent of in-school adolescents' engagement in risky sexual behaviours using a 4-point Scale of Very High Extent (VHE), High Extent (HE), Low Extent (LE) and Very Low Extent (VLE).

The copies of the instruments were given to three experts for face validation. One expert each was selected from Department of Educational Foundations in the areas of Guidance and Counselling, and Childhood Development and another from the Department of Science Education in the area of Measurement and Evaluation, all from the University of Nigeria, Nsukka. The validates were required to assess and scrutinize the instrument with regard to the response format, appropriateness of the items and language clarity, especially as they relate to the purpose of the study.

In order to establish the internal consistency (reliability coefficient) of the instrument, the validated instruments were trial tested with30 eligible SSII in-school adolescents selected from four secondary schools (two in the urban area and two in the rural area) in IkotEkpene Education Zone of Akwa Ibom State, which lies parallel to the study area. Each inschool adolescents selected was given the three set of the instruments (ISAUCMCQ, ISARSBQ \&ISAPSEQ) to complete and return back to the researcher on the spot. The scores of students were collated and analyzed using Cronbach Alpha method. In-School Adolescents' Use of Computer-Mediated Communication yielded a reliability coefficient of 0.84 alpha, In-School Adolescents’ Risky Sexual Behaviours Questionnaire yielded a reliability coefficient of 0.98

The researchers visited each school used for the study with two research assistants. After brief discussion with the school principals about the purposes and the significance of the study in order to gain approval, the researcher solicited for the assistance of the school counsellors (where available) and the form teachers to mobilize the in-school adolescents that met the inclusion criteria for the study whose contacts were kept by the researcher during the pre-survey.

The study utilized correlational research design while Pearson correlation and linear regression where used for data analysis. The result of data analysis for the research question was interpreted using real limit of numbers as follows: very high extent (3.50-4.00), high extent (2.50-3.49), low extent (1.50-2.49), very Low Extent (0.50-149). The decision rule for testing the hypothesis was to reject the null hypothesis if the exact probability value (p-value) is less than the $a$ priori probability value (0.05 level of significance), otherwise do not reject. In addition, line graph was plotted to confirm the relationship between computer-mediated communication and risky sexual behaviours among in-school adolescents.

\section{RESULTS}

\section{Research Question}

The research questions in the study were answered as follows:

Research Question: What is the relationship between computer-mediated communication and risky sexual behaviour among in-school adolescents in regards to students' physical location? 
Table 1: Partial Correlation Analysis Showing the Correlation of Computer-Mediated Communication with Risky Sexual Behaviours among in-School Adolescents in Regards to Students' Physical Location

\begin{tabular}{|l|c|c|c|c|}
\hline \multicolumn{1}{c|}{ Variables } & $\mathbf{N}$ & $\bar{X} \mathbf{S D}$ & $\mathbf{r}_{\boldsymbol{p}}$ & Decision \\
\hline CMC & 415 & $3.37 \pm .33$ & & \\
\hline RSB & 415 & $3.27 \pm .36$ & .74 & High Extent \\
\hline Location & 415 & $1.46 \pm .50$ & & \\
\hline
\end{tabular}

$\mathrm{CMC}=$ Computer-mediated communication, $\mathrm{RSB}=$ Risky Sexual Behaviour, $\mathrm{n}=$ number of respondents that experience each parenting style,rp=Partial correlation coefficient

Results in Table 1 show that the mean score for computer-mediated communication is 3.37 with standard deviation of 0.33 ; the mean score for risky sexual behaviours is 3.27 with standard deviation of 0.36 ; while the mean score for parenting styles is 1.46 with a standard deviation of .50 . The value of the partial correlation coefficient $\left(\mathrm{r}_{p}\right)$ which is 0.74 indicates that the extent location mediates the relationship between computer-mediated communication and risky sexual behavioursis high.

\section{Hypothesis}

The relationship between computer-mediated communication and risky sexual behaviours among in-school adolescents will not be significant in regards to students' physical location.

Table 2: Summary of Regression Analysis Showing the Relationship between Computer-Mediated Communication (CMC) and Risky Sexual Behaviour (RSB) among in-School Adolescents in Regards to Students' Physical Location

\begin{tabular}{|l|c|c|c|c|c|c|}
\hline \multicolumn{1}{|c|}{ Variables } & $\mathbf{N}$ & $\mathbf{F}$ & $\mathbf{R}^{2}$ & $\mathbf{B}$ & Sig. & Decision \\
\hline CMC & & & & & & \\
\hline RSB Location & 415 & 386.63 & .652 & .687 & .000 & Rejected \\
\hline
\end{tabular}

Predictors: (Constant), CMC, location. Dependent Variable: RSB; df $=1,412 ; \mathrm{p}<.05$

The results in table 2 showed that the relationship between computer-mediated communication and risky sexual behaviours was significant in regards to students' physical location, $R^{2}=.65, F(1,412)=386.63, \beta=.69$, $p<.05$. Since the exact probability value (.000) is less than the a priori probability value $(0.05)$, the null hypothesis which states that the relationship between computer-mediated communication and risky sexual behaviours among in-school adolescents will not be significant in regards to students' physical location is rejected.

\section{DISCUSSIONS}

The study examined the relationship of computer-mediated communication with risky sexual behavioursin regards to students' physical location. The study shows that the relationship between computer-mediated communication and risky sexual behaviours was statistically significant in regards to students' physical location. Thus, the study demonstrated that students' physical location significantly influences the relationship between computer-mediated communication and their risky sexual behaviours. This could be due to the availabilities of some basic social amenities like good roads, internet services, GSM networks, electric power supply and health facilities among others in the urban area than in the rural area as reported by UNESCO (2012). This finding is in agreement with Koovakkai \& Muhammed (2010) who observed that risky sexual behaviour of adolescents in the rural and urban areas tends to differ based on the differences in their engagement in computer-mediated communication or social networks. The finding further lend credence to Dineshan and Said (2010) who opined that, as compared to the urban adolescents, the internet abuse in terms of habit of changing/manipulating information on the internet, opinion about giving false information on the internet, habit of downloading vulgar pictures/pornographic items, plagiarism, tendency of sending unwanted messages is more among the rural adolescents 
since there is lack of social media orientation in the rural area. This finding is congruent with Atav and Spencer (2002) who observed that rural dwelling students engage in risky sexual activities more than urban ones and Voeten, Egesah and Habbema (2004) who noted that sexual behaviour was more risky in rural than in urban areas because rural area does not have necessary devices for computer-mediated communication as compared to urban areas. Urban-dwelling in-school adolescents, therefore, have more tendencies to use computer-mediated communication systems than rural-dwelling inschool adolescents. The rural-dwelling in-school adolescents with their rustic curiosity explore and experiment the possibilities of computer-mediated communication systems and often fall victims of such communications since they may not have adequate knowledge about how computer-mediated communication could be used without harm. In the other hand, the urban in-school adolescents may have the opportunity of getting more information about the use as well as misuse of computer-mediated communication. Consequently, the use of computer-mediated communication in the rural and urban areas differs with regard to risky sexual behaviour.

Students' physical location could influence the relationship between computer-mediated communication and risky sexual behaviours because sometimes in-school adolescents from the rural area do not have consistent electric power supply to power their computerized devices. Also, they may experience poor network and low access to computerized devices and credit cards unlike their counterparts from urban area. This notwithstanding, some in-school adolescents in the rural area are still having access to network, internet, cell phone, generating set, laptop and other facilities that enable them participate in computer-mediated communication and thus engage in risky sexual behaviours. Again, it should be noted that urban in-school adolescents may have access to information and orientation regarding computer-mediated communication and risky sexual behaviour more than their rural counterparts. Hence, the consequences of the computermediated communication and risky sexual behaviours may be more pronounced in the rural area than in the urban area. Particularly, the consequences of risky sexual behaviour on the rural-dwelling in-school adolescents is high because there is lack of accurate and adequate social media and sexuality orientation in the rural area. This is why more victims of unwanted pregnancy, unsafe abortion, early marriage and sexually transmitted infections are found in the rural area more than in the urban.

The finding of the study implies that the availability of modern infrastructures including internet centers, hotels, recreational centers, hospitals, good roads, and mobile network access, among others may directly or indirectly influence adolescents' engagement in computer-mediated communication and risky sexual behaviours. For instance, in the urban area where these things are available, many in-school adolescents are prone to the risk of computer-mediated communication than their counterparts in the rural areas. To this end, there is tendency that in-school adolescents in the urban area will be more exposed to life enhancement programmes like counselling, sexuality education, social network orientation as well as seminars and workshops that address sexual issues more than their counterparts in the rural area. Thus, the in-school adolescents in the rural area may remain disadvantageous in terms of lack of adequate and accurate information regarding the use of computer-mediated communication and risky sexual behaviours while in-school adolescents in the urban area will continue to exposed to computer-mediated mediated communication and risky sexual behaviours if nothing is done to help in-school adolescents in both urban and rural areas to control their engagement in computer-mediated communication and risky sexual behaviours.

It was challenging drawing sample from rural and urban schools since they were not evenly distributed. This led to the use of multi-stage sampling method to select the number of in-school adolescents that gave each location direction. 
Again, it was not easy for the students to understand the concept of computer-mediated communication and risky sexual behaviours until they were enlightened. Due to privacy issue, some of the respondents appeared to be sensitive in giving honest responses. However, the researcher and the research assistants explained to the respondents that the information needed were for research purpose only.

\section{CONCLUSIONS}

In conclusion, the correlation between computer-mediated communication and risky sexual behavior among in-school adolescents was statistically significant in regards to students' physical location.

\section{REFERENCES}

1. Achebe, C. (2000). Common careers for personality types. Retrieved from www.personalitytype.com/hu/2/fag.

2. Ajuwon, A., Olley, B. O., Akin-Jimoh, I. \&Akintola, O.(2001). Experience of sexual coercion among adolescents in Ibadan, Nigeria.African Journal of Reproductive Health, 5 (3):120-131.

3. Ajzen, I. (1991). The theory of planned behaviour. Organizational Behaviour and Human Decision Processes, 50(2): 179-211. Doi: 10.1016/0749-5978(91)90020-T.

4. Ajzen, I. (2002). Perceived behavioural control, self-efficacy, locus of control, and the theory of planned behaviour.Journal of Applied Social Psychology, 32: 665-683.

5. Atav, S. \& Spencer, G. A.(2002). Health risk behaviours among adolescents attending rural, suburban, and urban schools: a comparative study. Family \& Community Health, 25 (2): 53-64.

6. Azikiwe, U, (2001). Gender issues and the universal basic education programme. The Nigerian UBE Journal, 1(2): 371-378.

7. Azikwe, U. (2000). Gender issue and universal basic education programme. Lead Paper presented at University of Nigeria, Nsukka, 3-7 July, 2000.

8. Baltes, B. B., Dickson, M.W., Michael, P., Sherman, M. P., Cara, C., Bauer, C. C.\&LaGanke, J.(2002).Computer mediated communication and group decision making: a meta analysis. Organizational Behaviour and HumanDecision Processes, 87(1):156-179. doi:10.1006/obhd.2001.2961.

9. Bandura, A. (1977). Social learning theory. New Jessey: Englewood Cliff Prentice Hall Inc.

10. Barnes, S. B. (2009). Relationship networking: society and education. Journalof Computer-Mediated Communication, 14: 735-742.

11. Baruah, Himakshi, PragayaDashora, and ArtiParmar."Impact of Cyberbullying on Psychological Health of Adolescents." International Journal of Humanities and Social Sciences (IJHSS) 6.4 (2017): 137-144.

12. Bassaw, S.A. (1991). Gender roles.In H. Therney (ed.), Women's Studies Encyclopedia. New York: Peter Bederick.

13. Baumrind, D. (1991). Child care practices anteceding three patterns of preschool behaviour. Genetic Psychology Monographs, 75(1): 43-88.

14. Baumrind, D. (1991). Effective parenting during the early adolescent transition. In P. A. Cowan \& E. M. Hetherington (eds.), Family Transitions (pp. 111-163). Hillsdale, NJ: Erlbaum.

15. Berkman, F. (2010).Social Networks and Health. WHO Geneva. Retrieved from www.who.int/healthinfo/15

16. Bersamin, M., Michael, T., Fisher, Hill, D. L., Grube, J. W. \& Walker, S.(2008). Parenting practices and adolescent sexual behaviour: A longitudinal study. Journal of Marriage \& Family, 70(1): 97-112. doi: 10.1111/j.1741-3737.2007.00464.x 
17. Bishop, J. (2009). Enhancing the understanding of genres of web-based communities: the role of the ecological cognition framework. International Journal of Web-Based Communities, 5(1): 4-17.

18. Bordia, P. (1997). Face-to-face versus computer-mediated communication: a synthesis of the experimental literature. The Journal of Business Communication, 34: 99-120.

19. Bubas, G. (2001). Computer-mediated communication theories and phenomena: factors that prevent collaboration over the internet. Paper submitted to the 3rd CARNET users conference, Zagreb, September 24-26, 2001.

20. Campbell, S. W. \& Park. J. Y.(2014). Predictors of mobile sexting among teens: Toward a new explanatory framework. Mobile Media \& Communication, 2(20): 232-249.doi: 10.1177/2050157913502645.

21. Centers for Disease Control and Prevention (2010).Youth Risk Behaviour Surveillance-United States, 2009. MMWR, 59 (SS5):1-142. Retrieved from http://www.cdc.gov/mmwr/preview/mmwrhtml/ss5905a1.htm.

22. Centers for Diseases and Control and Prevention (2010).Diagnoses of HIV infection and AIDS in the United States and dependent areas, 2009.HIV Surveillance Report, vol. 21.Retrieved from http://www.cdc.gov/hiv/topics/surveillance/resources/reports/.

23. Center for Internet and Society, Harvard Law School, Internet Safety Technical Task Force. (2010). Enhancing safety and online technologies:final report of the internet safety task force to the multi-state working group on social networking for the state attorneys of the Uneral States. Retrieved from http://cyber.law.harvard.edu/sites/cyber.law.harvard.edu/files/ISTTF_Final_Report.pdf.

24. Chewning, B. \&Koningsfeld, R. V. (1998). Predicting adolescent's initiation of intercourse and contraceptive use.Journal of Applied Social Psychology, 28:1245-1285.

25. Chigbu, E.F. (2011). Relationship between personality and career choice of secondary school students in Enugu State.Unpublished M.Ed Thesis, University of Nigeria, Nsukka.

26. Cobb, S. C. (2009). Social presence and online learning: a current view from a research perspective. Journal of Interactive Online Learning, 8 (3), 241-254

27. Collumbien, M. (2014). Sexual behaviour in context: a global perspective. Lancet, 386: 1706-1728.

28. December, J. (1997).Notes on defining of computer-mediated communication.Computer-Mediated Communication Magazine, 4(2).Retrieved from http//:www.december.com/cmc/mag/.

29. DiClemente, R. J., G. M., Crosby, R., Sionean, C, Cobb, B., Harrington, K., Davies, S., Edward W., Hook, E.W. \& Kim, M. O. (2001). Parental monitoring: association with adolescents' risk behaviours. Pediatrics, 107(6):1363-1368. doi: 10.1542/peds.107.6.1363.

30. Dimbuene, Z. T. \&Defo, B. K. (2011). Risky sexual behaviour among unmarried young people in Cameroon: another look at family environment. Journal of Biosocial Science , 43( 02):129-153. doi: http://dx.doi.org/10.1017/S0021932010000635.

31. Dineshan, K. D. \& Said, M. P. (2010). Internet abuse among the adolescents: a study on the locale factor. Webology, 7(1), Article 75. Retrieved from: http://www.webology.org/2010/v7n1/a75.html

32. Dunn., R., (2013). Identity theories and technology. East Tennessee, USA: East Tennessee State University Press.

33. Eze, C.O. (2005). Adolescent psychology. Enugu: Computer Edge Publishers.

34. Fatusi, A. O. \& Blum, R. W. (2008).Predictors of early sexual initiation among a nationally representative sample of Nigerian adolescents.BMC Public Health, 8:136 doi:10.1186/1471-2458-8-136. 
35. Faurell, W. \&Sterba, J. P. (2008).Does feminism discriminate against men? A debate. New York: Oxford University Press.

36. Feldman, S. \& Brown, N. (1993). Family influences on adolescent male sexuality: the mediational role of self-restraint. Social Development, 2:15-35.

37. Francesco, S. (2000). China's floating population a headache for census. The Straits Times, 22 September, 2000.

38. Garrett, S. (1992). Gender. New York: Routledge.

39. Glen-Spyro, C. (2010). Risky sexual behaviour in adolescence. Retrieved from www.bellavidacetre.co.za.

40. Gunawardena, C. N. (2004). Designing the social environment for online learning: the role of social presence. In D. Murphy, R. Carr, J. Taylor, \& T. Wong (eds.), Distance education and technology: issues and practice (pp. 255-270). Hong Kong: Open University of Hong Kong Press.

41. Guzman, M. T. \&P ohlmeier, L. A.(2014). High-risk behaviours in youth. Retrieved from http://www.ianrpubs.unl.edu/pages/publicationD.jsp?publicationId.

42. Haffner, D. (1999). From diapers to dating: a parent's guide to raising sexually healthy children. New York: Newmarket Press.

43. Harrison, D. A., Mohammed, S., McGrath, J. E., Floret, A. T., \&Vanderstoep, S. W. (2003) Time matters in team performance: effects of member familiarity, entrainment, and task discontinuity on speed and quality. Personnel Psychology (56): 633-669.

44. Herring, S. (1994).Gender differences in computer-mediated communication: bringing familiar baggage to the new frontier. Texas: University of Texas.

45. Hersh, W.R., Hickam, D.H., Severance, S.M., Dana, T.L., Krages, K.P. \&Helfand, M., (2006) Diagnosis, access and outcomes: update of a systematic review.Telemedicine Services Journal, 2(1). Retrieved from www.ncbi.nlm.nih.gov/pubmed/16989671.

46. Hewett, P. C., Mensch, B. S., \&Erulkar, A. S. (2014). Consistency in the reporting of sexual behaviour by adolescent girls in Kenya: a comparison of interviewing methods. Sexually Transmitted Infection, 80: 43-48. doi:10.1136/sti.2004.013250.

47. Hindin J. M. \&Fatusi, A. O. (2009).Adolescents sexual and reproductive health in developing countries. Sexual and Reproductive Health, 35 (2).doi: 10.1363/3505809.

48. Hoffman, J. (2011, March 27). A girl's nude photo and altered lives.Retrieved from http://www.nytimes.com/2015/09/27/us/27sexting.html?pagewanted=all.

49. Honby, A. S. (2000). Oxford advanced learners dictionary 6th Edition. Oxford, New York.

50. Hoffman, L. (1991). Changes in family roles, socialization, and sex differences.American Psychologist, 32; 644-657.

51. Huebner ,A.J.\& Howell, L.W. (2003). Examining the relationship between adolescent sexual risk-taking and perceptions of monitoring, communication, and parenting styles.Journal of Adolescent Health, 33(2):71-78.

52. Igbo, J. N.(2008). Adolescent psychology.In P. N. Onwasoanya (Ed), Counselling psychology for Nigeria (pp. 31-42).Nsukka, Nigeria: GREAT AP Express publishers Limited.

53. Igbo, H. I., Egbe-Okpenge, E. G. \& Awopetu, R. G. (2013). Influence of information and communication technology on behaviour problems of Nigerian youths. JournalSbspro10(6). doi:10.1016/j.sbspro.2013.06.517.

54. Janson, C. (2013). Computer-mediated communication. Retrieved from http/www.techopedia.com.

55. Jiang, C. L., Bazarova, N. N., \& Hancock, J. T. (2011). The disclosure-intimacy link in computer-mediated communication: an attributional extension of the hyperpersonal model. Human Communication Research, 37:58-77. 
56. Jiang, C., Bazarova, N., \& Hancock, J. (2011). From perception to behaviour: disclosure reciprocity and the intensification of intimacy in computer-mediated communication. Communication Research, 40:125-143.

57. Johnson, K. (2014). Examples of different forms of technology - mediated communication.Retrieved from http//:www. Smallbusiness.chron.com/example.

58. Kelly, A. E.\& McKillop, K. J. (1996). Consequences of revealing personal secret.Psychological Bulletin, 120: 450-465.

59. Koovakkai, D. \& Muhammed, P., S. (2010). Internet abuse among the adolescents: a study on the locale factor. Webology,7(1),75. Retrieved from http://www.webology.org/2010/v7n1/a75.html.

60. Kotchick, B. A., Shaffer, A., \& Forehand, R. (2001). Adolescent sexual behaviour: a multisystem perspective. Clinical Psychology Review, 214: 493-519.

61. Lenhart, A, Purcell K, Smith, A., \&Zickuhr, K. (2010).Social media and mobile internet use among teens and young adults.Retrieved http://www.pewinternet.org/Reports/2010/Social-Media-and-Young-Adults.aspx.

62. Liau, A. K., Khoo, A. \& Hwaang, P. (2005). Factors influencing adolescents engagement in risky internet behaviour. Cyber Psychology \& Behaviour, 8(6):513-520. doi:10.1089/cpb.2005.8.513.

63. Ling, R. (2004). The mobile connection: the cell phone's impact on society. San Francisco, CA: Morgan Kaufman.

64. Longmore, M. A., Manning, W. D.\& Giordano, P. C. (2001). Preadolescent parenting strategies and teens' dating and sexual initiation: a longitudinal analysis. Journal of Marriage and the Family, 63: 322-335.

65. Metz, J. M. (1992). Computer-mediated communication: perceptions of a new context. Paper presented at the speech Communication Association annual conference, Chicago, IL.

66. Mohammadyari, G. (2013). The relationship between parental style and attitude to premarital sex among students: a case study in Iran. International Journal of Psychology and Behavioural Research, 3(1): 24-28.

67. Moreno, M. A., Brockman, L. N., Wasserheit, J. N. \& Christakis, D. A.(2012). A pilot evaluation of older adolescents' sexual reference displays on Facebook. Journal of Sex Research, 49 (4): 390-399. doi: 10.1080/00224499.2011.642903.

68. Moreno, M. A., Parks, M. R., Zimmerman, F. J., Kurth, A., \& Christakis, D. A. (2009). Reducing at-risk adolescents' display of risk behaviour on a social networking web site: a randomized controlled pilot intervention trial. Archives of Pediatric Adolescent Medicine, 163 (1):35-41. doi:10.1001/archpediatrics.2008.502.

69. National Reproductive Health, HIV \& AIDS Prevention and Care Project (2013). Manualfor training peer educators. Enugu State NYSC Batch B orientation pragramme.

70. Nevid, J. S. \&Rathus, S. A. (2005).Psychology and the challenges of life. London: John Wiley \& Sons.

71. Nwankwo, S. O. (2014). Adolescent sexuality needs and counselling services in senior secondary schools (SSS) in Kwali, Abuja. In A. A. Adegoke\& O. Aluede (eds.), Perspectives in guidance and counselling. Benin City, Nigeria: Justice-Jeco Printing and Publishing Global.

72. Nworgu, B. G. (2006). Educational research, basic issues and methodology.Nsukka, Enugu State: University Trust Publishers.

73. Okafor, I.\& Obi, S. N. (2005).Sexual risk behaviour among undergraduate students in Enugu, Nigeria.Journal of Obstetrics \& Gynaecology 25(6):592-595 doi:10.1080/01443610500239511.

74. Olaitan, S.O. \&Ndomi, B.M. (2000) Vocametrics: a high-tech problem solving quantitative text with computer skills. Onitsha: Cape Publishers. 
75. Olugbenga-Bello, A. I., Adebimpe, W. O. \& Abodunri, O. L. (2009). Sexual risk behaviour among in-school adolescents in public secondary schools in a Southwestern City in Nigeria. International Journal of Health Research, 2(3): 243-251.

76. Oluwatosin S. A. \&Adediwura A. A. (2010).Undergraduates' History of Sexual Abuse, Parenting Style and Sexual Risk Behaviour in Southwestern Nigeria. An International Multi-Disciplinary Journal, Ethiopia, 4 (2): 139-155)

77. Onyenze-Chukwu, C.C. (2003). Secondary school adolescents values as correlate of their adjustment problems.Unpublished Ph.D Thesis, University of Nigeria, Nsukka.

78. Orratai R., C, A., Fongkaew, W., Rosati, M. J., Miller, B. A.\&Cupp, K. (2010).Parenting and adolescent problem behaviours: a comparative study of sons and daughters in Thailand. Journal of Medical Association of Thailand, 93(3): 293-300.

79. Perry, T. S. (1992). E-mail at work. IEEE Spectrum, 29: 24-28.

80. Poindexter, B. (2013). Examining intersectionality theory and adolescent motivations to engage in risky sexual behaviour.Retrieved fromhttp://digitalcommons.uri.edu/theses.

81. Pollard, M. S. \& Morgan, S.P (2002).Emerging parental gender indifference) sex composition of children and the third birth.America Sociological Review, 67: 600-613.

82. Postmes, T., Spears, R. \& Lea, M. (2013). Breaching or building social boundaries? sid-effects of computer-mediated communication. Communication Research, 25:698-715.

83. Postmes, T., Spears, R., Lee, A. T.\& Novak, R. J. (2005). Individuality and social influence in groups: inductive and deductive routes to group identity. Journal of Personality and Social Psychology, 89:747-763.

84. Ramirez, A. J.\& Zhang, S. (2007). When online meets offline: the effect of modality switching on relational communication. Communication Monographs, 74: 287-310.

85. Ramirez, A., Zhang, S. McGrew, N.\& Shu-Fang, L. (2007). Relational communication in computer-mediated interaction revisited: a comparison of participant-observer perspectives. Communication Monographs, 74(4):492-516. doi: $10.1080 / 036377507017165$.

86. Rajeswari, S., and J. O. J. G. Eljo. "A study on emotional adjustment of adolescent school students." International Journal of Humanities Social Sciences 2.2 (2013): 49-56.

87. Revathi, T N, and M. Chetan. "Epidemiological and Clinical Study of Various Sexually Transmitted Diseases Among Female Commercial Sex Workers. "International Journal of General Medicine and Pharmacy (IJGMP) 4.1, Jan 2015, 23-36

88. Rizzoli, M.A., Schurch, M.A., Chevalley, T. \& Bonjour, J.P.(1998). Protein intake and oesteoporosis. In R. P. Burckhardt, B. Dawson Hughes \& R. P. Heaney (Eds). In nutritional aspects of oesporosis.(PP.141-154). Springer, New York.

89. Saewyc, E. M., Magee, L. L. \& Pettingell, S. E. (2004). Teenage pregnancy and associated risk behaviours among sexually abused adolescents. Perspective on Sexual and Reproductive Health, 36 (4): 98-105.

90. Santrock, J. W. (2007). A tropical approach to life-span development. New York. NY: McGraw-Hill Companies, Inc.

91. Scott, C. R. (2009). A whole-hearted effort to get it half right: predicting the future of communication technology scholarship. Journal of Computer-Mediated Communication, 14: 753-757.

92. Sexual Health Center (2014).High-risk sexual behaviour - topic overview. Retrieved from www.webmd.com/sex/tc/high-risksexual.

93. Short, J., Williams, E., \& Christie, B. (1976).The social psychology of telecommunications. London: John Wiley \& Son. 
94. Sieverding, J. A., Adler, N., Witt, S., \& Ellen, J. (2005). The influence of parental monitoring adolescent sexual initiation. Archives of Pediatric Adolescent Medicine, 159: 724-729.

95. Slap, G. B., Huang, B., Daniyam, C. A., Zink, T. M. \& Succop, P. A. (2003). Sexual behaviour of adolescents in Nigeria: cross sectional survey of secondary school students. BMJ, 326 (15).doi: http://dx.doi.org/10.1136/bmj.326.7379.15.

96. Slaymaker, E., Walker, N., Zaba, B. \& Collumbien, M. (2014). Chapter 14: unsafe sex. Geneva:World Health Organization. Retrieved from www.who.int/publications/cra/chapters/volume2/1177-1254.pdf.

97. Smith, L. H., Guthrie, B. J., \& Oakley, D. J. (2005). Studying adolescent male sexuality: where are we? Journal of Youth Adolescent, 34: 361-77.

98. Stacey, A. G. (2003). Educational statistics for the behavioural sciences. London: John Wiley \& Son.

99. Stang, J. \& Story, M. (eds) (2005). Guidelines for Adolescent Nutrition Services.Retrieved from www.sciepub.com/reference/72570.

100. Super, C. M., \& Harkness, S. (1999). The environment as culture in developmental research. In S. L. Friedman, \& B. T. D. Wachs (eds.), Measuring environment across the life span: emerging methods and concepts (pp. 279-323).Washington, D.C.: American Psychological Association.

101. Sussman, N. M. \& Tyson, D. H. (2000). Sex and power: gender differences in computer-mediated interactions. Computers in Human Behaviour 16: 381-394.

102. Tannen, X. (1990). You just don't understand: women and men in conversation. New York: William Morrow.

103. The Nielsen Company. (2009). How teens use media: a Nielsen report on the myths and realities of teen media trends in US.Retrieved from website:http://www.nielsen.com/content/corporate/us/en/search.html?q=How+Teens+Use+Media.

104. Udaya, C.O. (2010). Gender issues in international politics and the millennium development goals. Journal of Arts and Social Science Review, 3(1): 177-184.

105. Udom, I. E. \&Otu, M. S. (2013).Adolescents' sexual challenges and academic underachievement amongst female adolescents in uyo metropolitan city. African Journal of Education and Information Management, $15(1$ \& 2):11-23.

106. Ulin, P. R.(1992). African women and AIDS: negotiating behavioural. Soc. Sci. Med., 34:63-73.

107. UNICEF (2014).Annual report.Retrieved from www.unicef.org/publications/index_73682.html.

108. Vassallo, D.J., Swinfen, P., Swinfen, R. \& Wootton, R. (2001).Experience with a low-cost telemedicine system in three developing countries. Journal of Telemedicine Telecare, 7: 56-58.

109. Verma, Jyotsna, and Archana Kumari. "A study on addiction to social networking sites and psychological well-being among working adults.,.." International Journal of Humanities and Social Sciences”(IJHSS) (2016): 5-153.

110. Voeten, H. A., Egesah, O. B. \&Habbema, J. F. (2004). Sexual behaviour is more risky in rural than in urban areas among young women in Nyanza Province, Kenya. Journal of American Sexually Transmitted Diseases Association, 31 (8): $481-487$.

111. Walther, J. B. (1996). Computer-mediated communication: impersonal, interpersonal, and hyperpersonal interaction. Communication Research, 23: 3-43.

112. Walther, J. B., \& Burgoon, J. K. (1992).Relational communication in computer-mediated interaction.Human Communication Research, 19: 50-88.

113. Whitley, B. E. (1997). Gender differences in computer-related attitudes and behaviour: a meta-analysis. Computers in Human Behaviour, 13(1):1-22 doi: 10.1016/S0747-5632(96)00026. 

Adolescent Students Physical Location

114. Witmer, D. F. (1997). Risky business: why people feel safe in sexually explicit on-line communication. Journal of ComputerMediated Communication, 2(4).doi: 10.1111/j.1083-6101.1997.tb00199.

115. World Health Organization (2002).Reducing risks, promoting life. Retrieved from www.who.int/whr/2002/.

116. World Health Organization (2013).Safe abortion.Technical and Policy Guidance for Health Systems, 5(2): 123-134. Retrieved from www.who.technical/policy.

117. Yen, H. (2011-07-28).Rural US disappearing? Population share hits low. ABC New, Associated Press.12:08 AM. Retrieved from www.news.yahoo.com/rural-us-disappearing-population-share-hits-low-20581.

118. Yu, B. (2011). Computer-mediated communication systems. Triple C., 9(2):531-534. Retrieved from http/www.triple-ct.

119. Zimmer-Gembeck, M. J., \&Helfand, M. (2008). Ten years of longitudinal research on U.S. adolescent sexual behaviour: developmental correlates of sexual intercourse, and the importance of age, gender and ethnic background. Developmental Review, 28: 153-224. 

